\title{
Climate change impacts and adaptive strategies: Lessons from the grapevine
}

Article in Global Change Biology · July 2016

DOI: $10.1111 /$ gcb.13406

CITATIONS

0

5 authors, including:

\section{Jonathan Mosedale}

University of Exeter

16 PUBLICATIONS 473 CITATIONS

SEE PROFILE

Ilya M. D. Maclean

University of Exeter

68 PUBLICATIONS 663 CITATIONS

SEE PROFILE

\section{Robert J Wilson}

University of Exeter

72 PUBLICATIONS $\quad 4,558$ CITATIONS

SEE PROFILE

Some of the authors of this publication are also working on these related projects: 
Received Date : 16-Feb-2016

Revised Date : 09-Jun-2016

Accepted Date : 13-Jun-2016

Article type : Research Review

\section{Climate change impacts and adaptive strategies: lessons from the grapevine}

Running head: Lessons from the grapevine

Authors and affiliations: Jonathan R. Mosedale ${ }^{1 *}$, Kirsten E. Abernethy ${ }^{1}$, Richard Smart ${ }^{2}$, Robert J. Wilson ${ }^{3}$, Ilya M.D. Maclean ${ }^{1}$

${ }^{1}$ Environment and Sustainability Institute, College of Life and Environmental Sciences, University of Exeter, Penryn Campus, Penryn, TR10 9FE, United Kingdom.

${ }^{2}$ Smart Viticulture, 31 N Corner, Newlyn, Cornwall TR18 5JG, United Kingdom.

${ }^{3}$ College of Life and Environmental Sciences, Hatherly Building, Prince of Wales Road, Exeter, EX4 4PS, United Kingdom.

Corresponding author: Tel: +44 (0) 1326 259490; e-mail: J.Mosedale@exeter.ac.uk

Keywords: viticulture, wine, climate change, grapevine, phenology, risk, adaptation, provenance
Abstract
The cultivation of grapevines for winemaking, known as viticulture, is widely cited as a climate-sensitive agricultural system that has been used as an indicator of both historic and contemporary climate change. Numerous studies have questioned the viability of major
This article has been accepted for publication and undergone full peer review but has not been through the copyediting, typesetting, pagination and proofreading process, which may lead to differences between this version and the Version of Record. Please cite this article as doi: $10.1111 / \mathrm{gcb} .13406$
This article is protected by copyright. All rights reserved. 
viticulture regions under future climate projections. We review the methods used to study the impacts of climate change on viticulture in the light of what is known about the effects of climate and weather on the yields and quality of vineyard harvests. Many potential impacts of climate change on viticulture, particularly those associated with a change in climate variability or seasonal weather patterns, are rarely captured. Key biophysical characteristics of viticulture are often unaccounted for, including the variability of grapevine phenology and the exploitation of microclimatic niches that permit successful cultivation under sub-optimal macroclimatic conditions. We consider how these same biophysical characteristics permit a variety of strategies by which viticulture can adapt to changing climatic conditions. The ability to realise these strategies, however, is affected by uneven exposure to risks across the winemaking sector, and the evolving capacity for decision-making within and across organizational boundaries. The role grape provenance plays in shaping perceptions of wine value and quality, illustrates how conflicts of interest influence decisions about adaptive strategies within the industry. We conclude by considering what lessons can be taken from viticulture for studies of climate change impacts and the capacity for adaptation in other agricultural and natural systems.

\section{Introduction}

Climate change poses a threat to the long-term viability of both agricultural and natural systems (Porter et al., 2014; Thomas et al., 2004). The biological and physical characteristics of these systems will affect their exposure and response to climatic change (Maclean et al., 2015), but so too will management practices (Howden et al. 2007, Greenwood et al. 2016), social-economic and cultural factors (Grothmann \& Patt, 2005; Adger et al., 2008). 
The methods used to downscale the projections of climate models and assess their impacts have been subject to frequent review (Mearns et al., 2001; Rosenzweig et al., 2013; Wilby \& Dawson, 2013 Ashcroft et al., 2009; Kearney \& Porter, 2009; Pacifici et al., 2015). However, the suitability of different methods and approaches can only be fully assessed within the context of particular ecological or agricultural systems. Methodological recommendations require an understanding of how well they capture system characteristics that mediate the adverse impacts of climate change and offer mechanisms of adaptation. Furthermore, the credibility of information about climate change is reduced in the eyes of practitioners and decision-makers by any failure to identify key effects of climate on specific systems or to recognize the requirements and implications of adaptation.

In this review we critically examine the methods used to capture the impacts and implications of climate change on a specific agricultural system widely cited within the global change literature. The cultivation of grapevines for wine production, or 'viticulture', provides an excellent case study, not only because of over thirty years of publications on the effects of climate change, but also because of the variety of methodological approaches taken and the socio-economic transformation of the industry over recent decades.

The gross domestic product worth of the global wine sector has been estimated at 58,600 billion USD (Anderson \& Nelgen 2011) and plays a significant role in several national economies. The major world viticulture regions (predominantly of Vitis vinifera L.) are found at latitudes lying between the mean annual $10^{\circ} \mathrm{C}$ and $20^{\circ} \mathrm{C}$ isotherms (de Blij, 1983), although viticulture is also found outside of this range, including the tropics where grapevines may exhibit no winter dormancy and produce more than one crop per year 
(Conceição and Tonietto, 2005). Individual grapevine cultivars, many of which are associated with particular wine styles that have endured over centuries (Bowers et al., 1999; This et al., 2006; Myles et al., 2011), possess more restricted distributions. Winemaking has been described as a natural resource-based industry organized around site-specific characteristics (Centonze, 2010) that are seen as intimately associated with wine quality, and find expression in the importance often given to wine provenance and the concept of 'terroir', of which climate is an integral part (Vaudour, 2002; van Leeuwen \& Seguin, 2006; White et al., 2009). Seasonal variability in the prevailing climate is also important in determining year-on-year variation in the yield, quality and value of harvests (Ramirez, 2008), reflected in the concept of wine vintages of varying quality.

Viticulture has been used as an indicator of both historic (Chuine et al., 2004; Meier et al., 2007) and contemporary climate change (Rodo \& Comin, 2000; Duchêne \& Schneider 2005; Bock et al 2011), and has become a cause célébre within the global change biology literature. Studies suggest major changes to the suitability of existing viticulture regions or grapevine cultivars, which implies significant social and economic consequences for a global industry in which cultivar and provenance are key indicators of product value and typicity (Bailly 2000; Schamel \& Anderson 2003).

The wine industry also exemplifies the impacts of globalization (Anderson, 2003, Hussein et al., 2008), with the development of new regions of production and consumption, expansion in international trade and technological innovation. Despite the evolving socioeconomic context of winemaking, many studies continue to adopt a primarily biophysical approach with limited consideration of how climate change impacts interact with the wider risk context. Conflicting 
evidence on the adoption of measures by the winemaking and viticulture industries to reduce future impacts (Galbreath, 2014; Alonso \& O’Neill, 2011; Lereboullet et al., 2013a) raises questions about the relevance of climate change information and how it is communicated to the industry (Lemos et al., 2012).

In this review we eschew particular theoretical frameworks to consider how research from across disciplinary divides both complements and challenges their respective findings. We draw upon the scientific literature and industry experience to (i) review the methods used to assess the biophysical impacts of climate change on viticulture; (ii) outline significant limitations to these methods in the light of the multiple determinants of harvest quality and yield, grapevine phenology and the association of viticulture with topographical niches; (iii) explore the capacity for adaptation within the industry and the importance of key socioeconomic factors on adaptive decision-making; and (iv) examine what lessons may be drawn for assessing impacts on ecological and agricultural systems, and how information on the impacts of climate change can be made more relevant to the industry.

\section{Measuring climate change impacts on viticulture}

The impacts of climate change on viticulture are projected to vary between different winemaking regions. Where viticulture is restricted by a shorter growing season and/or low summer temperatures, such as higher latitude or elevation regions, suitability is expected to improve under future climate conditions as higher temperatures permit the growing of a wider range of cultivars, more reliable yields and the production of better quality wines (Lough et al., 1983; Kenny \& Harrison, 1992; Jones et al., 2005). In contrast, major reductions in quality and in the area suitable for premium grape production are anticipated in several existing winemaking regions, primarily due to projected increased summer 
temperatures and lower precipitation (White et al., 2006; Webb et al., 2008; Mira de Orduña, 2010; Hannah et al., 2013). The adoption of new varieties and/or the migration of vineyards to new regions and/or higher elevations have been suggested as likely consequences of climate change (White et al., 2006; Hall \& Jones, 2009; Salinger, 1987; Jones et al., 2005; Lobell et al., 2006; Hannah et al., 2013; Moriondo et al., 2013; Fraga et al., 2014b). However, the implications drawn by many studies have been challenged and doubts expressed about how well the methodologies and metrics used to describe the effects of future climate conditions capture key aspects of viticulture that may augment or mitigate the impacts of change (Keller, 2010; Sadras \& Moran, 2013; van Leeuwen et al., 2013).

\section{Climate determinants of yield, quality and phenology}

The economic viability of viticulture depends not only on the size and variability of yields but also on harvest quality and suitability for winemaking, which are unrelated to overall biomass production (Ollat et al., 2002). The physical and chemical composition of harvested grapes interacts with the winemaking and conservation process to determine wine quality: a concept difficult to quantify but which has an important sensory aspect determined in part by grape composition which in turn is affected by grapevine genotype, environmental conditions and cultivation practices (Jackson \& Lombard, 1993; Verdú Jover, 2004; Lund \& Bohlmann, 2006).

Adequate growing season temperature is recognized as essential to vineyard yields (Sánchez \& Dokoozlian, 2005), fruit quality (Bonada \& Sadras, 2015) and grapevine phenology (Chuine et al., 2004; Petrie \& Sadras, 2008; Xu et al., 2012), but a range of other climatic variables and weather events can also act as limiting factors, the importance of which varies 
between different climatic conditions and types of viticulture (Nesbitt et al., 2016).

Harvest yields are determined by the number and size of grape clusters formed (Petrie and Clingeleffer 2005), which are affected not only by average seasonal conditions but also by weather conditions at key stages of vine development that include bud initiation in the previous season (Pratt, 1971; Keller \& Koblet, 1995; Watt et al., 2008), budbreak (Pouget, 1981; Petrie \& Clingeleffer, 2005) and flowering (Koblet, 1966, May, 2000). The effects of extreme temperature and water stress on crop yields vary according to the stage of grape development (Kliewer, 1977) as does the impact of extreme weather events such as heavy rainfall or hail that can cause the complete loss of harvests (Willsher, 2013).

In terms of quality, higher growing season temperatures promote the accumulation of grape sugars and breakdown of organic acids: the traditional measures of grape maturity. Inadequate growing season temperatures will result in immature berries that are unsuitable for winemaking. Conversely, very high ripening temperatures can also reduce quality due to excessive sugar levels and low acidity, anthocyanin and flavonoid concentrations (Haselgrove et al., 2000; Downey et al., 2006; Sadras \& Moran 2012) which in turn reduce the aromatic properties of wines (Jackson \& Lombard, 1993; Mira de Orduña, 2010). Other facets of climate, such as solar radiation and precipitation, can affect the evolution of berry properties that may be quantitatively less significant but have a major effect on quality (Gonzalez-Barreiro et al., 2013, Pereira et al., 2006). Asynchronous fruit development associated with cold or rainy weather at flowering can also be a major cause of reduced harvest quality and/or yields. Optimal ripening conditions vary according to the varietal flavours of different cultivars and the requirements of different wine styles: as a result, different climates favour the production of grapes for particular types of wine. Many of the effects of climate on viticulture are mediated by grapevine phenology, which varies between grapevine cultivars (McIntyre et al., 1982) but is also responsive to 
temperature. More advanced phenology is observed under warmer growing conditions. Changes in the timing of budbreak or flowering will alter the conditions of later development according to seasonal weather patterns and the magnitude of the phenological shift. Phenological advancement may therefore augment the detrimental effects of climate change in Mediterranean regions by exposing ripening grapes to the higher temperatures and water stress that occur earlier in the season (Lereboullet et al., 2013b; Ramos et al., 2008).

Conversely, phenological advance could enhance the benefits of higher temperature in coolclimates by allowing grape ripening and harvest to occur in earlier, more favourable conditions.

The mediating effect of phenology can have surprising implications under some climate change scenarios. Exposure to late spring frosts, for example, has been projected to increase under some future climate-warming scenarios despite warmer temperatures due to an advance in budbreak (Molitor et al., 2014a; Mosedale et al., 2015). Exposure to many grapevine pathogens and pests, such as the European grapevine moth (Lobesia botrana), will also be affected by any change to the phenology of grapevines or the pest species (Caffarra et al., 2012).

\section{Biophysical modelling approaches}

Unlike many agricultural systems where crop yield models have dominated impact studies, many different measures of impact have been used to describe the effects of climate change on viticulture. The impacts of climate change have been most commonly described using (i) bioclimatic indices to map changes in land suitability for viticulture, (ii) the application of empirical models to future climate projections, or (iii) dynamic models that seek to simulate the effect of climate on the processes of crop growth and development. 
i. Suitability maps provide spatial representations of bioclimatic indices to describe changes in the suitability of land for viticulture under future climate conditions. Indices are often chosen a priori on the basis of their use in systems to classify different types of viticulture, such as those described by Amerine \& Winkler (1944), Gladstones (1992), Kenny \& Harrison (1992) and Tonietto \& Carbonneau (2004) among others. Alternatively indices may be selected from correlation analysis of a wide range of climatic variables with existing distributions of viticulture (Hannah et al., 2013; Moriondo et al., 2013), using methods similar to those applied in 'species distribution' and 'climate envelope' models used to assess impacts on ecosystem composition and species ranges (Guisan \& Thuiller, 2005; Hijmans \& Graham, 2006; Pacifici et al., 2015). Such methods have exploited the availability of gridded climate datasets (Hijmans et al., 2005; Haylock et al., 2008) to describe the implications of future climate projections across a national (Fraga et al. 2014b), continental (Kenny \& Harrison, 1992; White et al., 2006; Moriondo et al., 2013) or global scale (Hannah et al., 2013).

ii. Empirical models describing the statistical relationship observed between climate and viticulture variables have been applied to future climate projections. Empirical models can be used to relate variables across spatial and temporal scales, describing how macroclimate and large-scale atmospheric circulation patterns can be significant determinants of vineyard yields (Fraga et al. 2014c) conditions (Nemani et al., 2001; Santos et al., 2012), grapevine phenology (Marta et al., 2010; Webb et al., 2012) and the quality of wines (Jones \& Davis, 2000; Rodo \& Comin, 2000; Grifoni et al., 2006). Alternatively, models relating macroclimate to local climate parameters are used to statistically downscale (Hewitson et al., 2014) climate model outputs before applying models of the relationship between local climate and viticulture (Santos et 
al., 2011). Statistical models have been applied to measure climate change impacts on yield (Santos et al., 2011), grapevine pathogens (Francesca et al., 2006, Calonnec et al., 2008), and on various measures of harvest quality from vintage ratings (Jones et al., 2005; Moriondo et al., 2011) and harvest prices (Webb et al., 2008) to sugar content (Urhausen et al., 2011; Neumann \& Matzarakis, 2014) and other physicochemical properties of berries (Barnuud et al., 2013).

iii. Dynamic, or process-based, crop growth models have been widely used for measuring climate impacts on annual crops (Rötter \& Geijn, 1999; Rosenzweig et al., 2013) but have been less often applied to studies on viticulture. Dynamic models of grapevine growth range from growing season, field-scale simulation models primarily used as decision-support and forecasting tools, to functional models offering insight into specific plant physiological processes (Moriondo et al., 2015).

Several of the most widely used crop growth models have been applied to assess impacts of, and adaptation to, future climate projections. The general crop model STICS (Brisson et al., 2003) was adapted to assess impacts on viticulture at a national and regional scale (de Cortazar-Atauri, 2006; Brisson and Levrault, 2010; Muresu, 2012) and CropSyst (Stöckle et al. 2003) has also been used in several regional studies (Marsal and Utset, 2008; Mukaetov et al. 2013) focussing on implications for irrigation and water balance. VineLOGIC (Godwin et al., 2002) has been applied to assess impacts on Australian viticulture, particularly on phenology (Webb et al., 2007).

Although they vary in complexity, these crop growth models are composed of distinct but inter-related sub-models. Heat summation models of phenology have been widely used to model the effects of temperature on the timing of key phases of grapevine development such as budbreak, flowering and the onset of fruit ripening and 
colouration ('veraison') (Chuine et al., 2003; Duchene \& Schneider, 2005; Williams et al., 1985; Caffarra \& Eccel, 2011; Moncur et al., 1989; Xu et al., 2012). Other key elements of the main crop growth models include sub-models of canopy light (or photosynthetically active radiation) interception, biomass synthesis (using Radiation and/or Water Use Efficiency coefficients) and partitioning among vegetative, fruit and root organs either as a function of the phenological stage or as dynamic partitioning as a function of the 'sink' size and activity of different organs (White et al., 2016).

Climatic effects are generally captured by daily precipitation, radiation and maximum and minimum temperature variables. Environmental stresses, such as water or nutrient stress, are typically captured by empirical calibration of their effect on crop parameters such as RUE, or by the correction of biomass accumulation.

Dynamic grapevine models focussing on specific applications such as canopy development and branching (Pallas et al., 2010), nitrogen dynamics (Nendel and Kersebaum, 2004), the effects of salinity (Ben Asher et al., 2006), soil water balance and intercropping (Celette et al., 2010) also offer the possibility of being adapted for use with future climate projections.

\section{Limitations to existing approaches}

The many different factors that can restrict harvest yields or quality vary across temporal and spatial scales. An increase in mean growing season temperature may allow global viticulture to extend into higher latitude regions and permit a wider variety of cultivars to be grown in cool-climate regions. However, on a regional scale, other factors such as the risk of adverse flowering weather or frost events can limit yields in many years and thereby restrict the economic viability of viticulture. Furthermore, existing distributions of cultivars or viticulture 
do not correlate with biological tolerance limits, but are also a product of historical and social factors. Cited tolerance limits, in terms of average growing season temperatures of cultivars, have been exceeded in several viticulture regions (van Leeuwen et al., 2013) as a result of historic warming. Phenotypic plasticity, including phenological response to temperature, viticulture management and the requirements of different winemaking styles will all affect the climatic limits within which viticulture is viable. Therefore bioclimatic indices used in suitability mapping, whether chosen a priori or from the analysis of existing distributions, will only capture a few aspects of future climate change the importance of which will vary between viticulture regions.

Viticulture is an example of a 'niche crop' (Challinor et al., 2015) with vineyards often associated with topographical features that shape local, mesoclimatic conditions and permit viable viticulture under marginal macroclimatic conditions. In higher latitude regions, therefore, vineyards are typically located on south-facing slopes to maximise growing season temperatures and solar radiation, while reducing frost risk. Aspect, slope, elevation or the proximity of a large water body modify not conditions to which crops are exposed including temperature, wind exposure and soil drainage (van Leeuwen et al., 2004; Bonnardot et al., 2005; Jones, 2006; Bonnardot \& Cautenet, 2009; Bonnefoy et al., 2013; Fraga et al., 2014a). Where vineyards are associated with particular topography, even mean viticulture conditions will diverge from regional and macroclimatic norms. Suitability maps based on uncorrected, low resolution climate projections are therefore liable to underestimate the fine-scale variability of conditions that might permit viticulture to remain viable under changing macroclimatic conditions.

The widespread use of empirical models in impact studies on viticulture is largely explained by their computational simplicity, less demanding data requirements than dynamic models and their ability to relate variables across temporal and spatial resolutions. Limitations 
include the difficulty of deriving causal effects from statistical correlations and whether the relationships they describe will apply under future climate projections given the multiple determinants of yield and quality.

The ability of empirical models to capture impacts relating to weather conditions at key stages of crop development depends upon their spatial and temporal resolution. Seasonal or monthly metrics can capture the impacts of a change to inter-seasonal climate variability, including the frequency of extreme events, but are less suited to capture the effects of any shift in seasonal weather patterns or the indirect effects of a change in grapevine phenology, both of which are likely to invalidate empirical models developed under current climatic conditions.

The 'decoupling' of local mesoclimate change from macroclimate change, together with the non-linear relationship between climatic conditions measured at different resolutions, can also restrict the validity of empirical models when applied across different temporal or spatial scales. For example the reliability of phenology models calibrated from regional temperatures or local weather station data when applied to vineyard conditions will depend on the heterogeneity of the landscape and other factors determining variation in local temperatures (Ollson \& Jönsson 2015) or phenological response. Divergence between vineyard conditions and macroclimatic or regional climates can vary diurnally and seasonally, and is often greatest during extreme weather events such as frosts or heatwaves (Madelin \& Beltrando, 2005; Bonnefoy et al., 2013). The rate of historic warming displays spatial variation (Ashcroft et al., 2009; Maclean et al., 2016) as a result of topography and terrain, and therefore future changes in the climatic conditions affecting viticulture will not necessarily be proportionate to changes forecast from global and/or regional climate models.

The theoretical benefits of dynamic models (Costa et al., 2015, Moriondo et al. 2015) include their ability to capture non-linear interactions between weather and viticulture, their basis on 
biological, causal processes and their potential to integrate the effects of climate with other factors including soil profiles, crop management practices, and perhaps most importantly for future climate change scenarios, the effects of elevated $\mathrm{CO}_{2}$ levels on grapevine growth and development (Bindi et al. 1996, Poni et al., 2006).

However, comparison studies of dynamic growth models of annual crops have reported variation in the yields predicted by different models (Rötter et al., 2012; Eitzinger et al., 2013). A greater proportion of the uncertainty in climate change impact projections has been attributed to variations among crop models than to variation among downscaled general circulation models (Asseng et al., 2013).

Plant growth and development differs under environmental stress, including water stress or extreme temperatures, and dynamic models vary in how they integrate the effects of environmental stress on model coefficients, such as RUE, or the partitioning of resources among plant organs. Synergistic and antagonistic interactions between different aspects of climate change adds to the complexity of simulating crop growth, with for example elevated CO2 levels increasing the optimal temperature for photosynthesis (Schultz and Stoll, 2009; Salazar-Parra et al., 2012) and decreasing transpiration (Ewert et al. 2002). The greater complexity of the vineyard system, compared with annual crops, presents additional challenges to the dynamic modelling of climate impacts.

There is no absolute distinction between the three approaches we have described. Dynamic models depend on statistically described empirical relationships of the processes they describe. Key elements of many crop growth models, including the use of 'growing degree days' to model changes in grapevine phenology, have a limited grounding in biological processes and are derived from statistical analysis of historic time-series. The suitability of heat summation models of grapevine phenology, whether applied in isolation or as a component of dynamic growth models, remains unclear due to inherent limitations of daily 
summation measures (Due et al., 1993; Gu, 2015). Experimental studies (Sadras \& Moran, 2013) have failed to replicate the high sensitivity to temperature (typically a 4-9 day advance in maturity per ${ }^{\circ} \mathrm{C}$ increase) of linear models based on the analysis of historic time series (Tomasi et al., 2011; Petrie \& Sadras, 2008; Kast \& Rupp, 2009; Sadras \& Petrie, 2011). The incorporation of a winter chilling requirement to simulate grapevine vernalization, correction for daylength or applying upper limits to daily temperature summation does not always improve model performance (de Cortázar-Atauri et al., 2009; Fila et al., 2014). Attempts to develop robust growing degree models (Caffarra \& Eccel, 2010; Parker et al., 2011) applicable to cultivars or conditions beyond those under which they have been calibrated, have had varying success. In some cases statistical models using monthly temperature averages have been found to outperform classic growing degree day models applied across winemaking regions (Malheiro et al., 2013; Fraga et al. 2016).

Both empirical and dynamic models of discrete phenological events or even of discrete growing seasons cannot capture the continuity of phenological development and the interplay between development and vegetative growth (Sadras \& Moran, 2013). Few models replicate an entire season of growth (Molitor et al., 2014b), let alone the full two-year grapevine reproductive cycle (Pratt, 1971). Bud initiation, biomass synthesis and storage during previous years can be important factors affecting grape yields and quality, and can play an important role in crop responses to environmental stress such as extended periods of high temperature or drought (Lobell et al. 2006).

In summary, different modelling approaches share many common challenges when it comes to assessing the impacts of climate change on viticulture, key among which are (i) the multiple and interacting climatic determinants of harvest yields and quality, (ii) the contingency of many impacts on grapevine phenology, and (iii) the divergence between vineyard and macroclimatic conditions. 
Many weather events restricting yields or quality display high spatial and temporal resolutions, and viticulture has long exploited fine-scale topographic niches affecting local conditions. The metrics and approaches used to model climate impacts need to reflect the factors that really matter to viticulture under current conditions, which vary between different climatic and winemaking regions. Studies need to be informed about how these factors are likely to vary under future climatic conditions not only by models but by consideration of grapevine biology and viticulture in regions with analogous conditions to future projections.

\section{Mechanisms and strategies of adaptation}

Biophysical models, despite their shortcomings, reveal how the impacts of future climate change on viticulture will affect not only harvest yields but also the suitability of different cultivars, grape qualities and the type of wines produced. Viticulture, however, has proved itself viable under a range of sub-optimal climates. The same mechanisms that render grapevine cultivation sensitive to climatic conditions also provide methods by which viticulture can adapt to future climate change by the selection and manipulation of vineyard conditions, plant responses and winemaking techniques.

Studies mapping changes in the suitability of existing viticulture regions under future climate projections can imply that adaptation requires the migration of entire viticulture regions towards higher elevation and/or higher latitude regions (White et al., 2006; Moriondo et al., 2013; Hannah et al., 2013). Less consideration is given to how the macroclimatic conditions under which viticulture can succeed are influenced by long and short-term adaptation of viticulture and winemaking techniques (Fraga et al., 2012; Fleming et al., 2015b).

Vineyard conditions and canopy microclimates are influenced not only by vineyard topography but also by the orientation of vine rows (Grifoni et al., 2008), planting density, 
ground cover (Celette et al., 2009), grapevine training and canopy management systems (Smart, 1985; Smart et al., 1990; Dry, 2000; Pieri \& Gaudillère, 2015). Crop protection against extreme temperatures is possible through the use of shading nets (Castellano et al., 2008; Shakak et al., 2008; Greer et al., 2011) or foliar sunscreens (Glenn et al., 2010). Exposure to risks contingent on phenology, such as late frost, can be reduced by a change of cultivars but also by changes to viticulture practices. Late pruning is used to delay budbreak to mitigate the risk of spring frost damage (Friend \& Trought, 2007). Changes to the leaf area to fruit weight ratio (Petrie \& Clingeleffer, 2006; Poni et al., 2009), by the removal of grape clusters or canopy pruning, can modify the speed of fruit development in response to excessively low or high temperatures (Keller, 2010; Parker et al., 2014). The adaptation of wine styles and winemaking techniques can help ensure that the requirements of winemaking better match the maturity and properties of fruit produced under changing climatic conditions. Longer-term, the maintenance of genetic diversity and the breeding and selection of more tolerant cultivars and rootstocks (Duchene et al., 2010) could improve viability under future climate projections.

\section{Adaptive decision-making}

To support adaptive decision-making within the winemaking industry there is a need not only for information on the impacts of climate change and mechanisms of adaptation, but also recognition of the uneven distribution of the costs and benefits of adaptation among industry participants.

Any adaptive strategy has implications that extend beyond the management of climate-related risks, and resistance to change cannot be overcome simply by the provision of better information about the likelihood or consequences of climate change. The decision to adopt a 
particular adaptive strategy by an individual or an organisation will depend upon their capacity to change, the perception of their vulnerability to climate change relative to other sources of risk, and the risks and opportunities associated with adaptation.

The capacity to change is determined not only by the potential of the underlying biophysical mechanisms, such as the phenological plasticity of grapevine cultivars or the potential to manipulate vineyard conditions, but also by socio-economic and cultural factors. Different strategies require different resources and impose uneven costs among participants within the winemaking industry. Adaptation strategies based upon changes to the cultivars grown or areas under cultivation have greater financial implications for viticulture than for most agricultural crops, due to the high capital costs of vineyard establishment and slow return on investment. Such strategies imply substantial or 'transformative' change (Rickards \& Howden, 2012) to the industry with widespread consequences. Changes to viticulture practice offer more incremental strategies of adaptation, but can place significant demands on the skills and resources of individual organisations and businesses. The high value of winegrapes permits more costly interventions to mitigate the impacts of unfavourable weather events than might be feasible for many crops. Nevertheless, the achievement of a more adaptable and responsive viticulture often depends upon improved risk monitoring and more tailored interventions that require investment in technological assets and skills, as well as increased production costs (Burrell et al., 2004; Hall et al., 2002; Holland \& Smit, 2010).

The perceived importance of climate change relative to other risks (Grothmann \& Patt, 2005) is shaped not only by the available information and resources but also by values rooted in cognitive, social and cultural factors (Slovic, 1987; Adger et al., 2003, 2008). The greater scepticism about the need for adaptation among Australian grape-growers compared with winemakers (Fleming et al., 2015a) reflects the heightened exposure of grape-growers to a variety of socioeconomic risks (Kiem \& Austin, 2013; Bryant \& Garnham, 2013) which 
claim priority over the risks associated with future climate change. Likewise the stronger practical and emotional attachment to place of grape-growers (Fleming et al, 2015b), compared with wineries, magnifies the risks of any shift in vineyard locations (Galbreath, 2014).

Risks extend beyond the immediate cost implications associated with adaptation, particularly where they imply changes to key indicators of market value and quality such as the grapevine cultivar or provenance of grapes. The capacity of viticulture to adapt to climate change is determined not only by the resources and attitudes of individual businesses and organizations, but also by the wider capacity for innovation within value chains (Park et al., 2012) or the geographical 'clusters' (Porter, 1998) of enterprises and supporting organizations that typify winemaking regions. The risks and benefits associated with adaptation are contingent on the resources and decisions of many different organizations and individuals within the sector. The time required to build supply-chain expertise and market demand for new varieties in Australia, for example, has been estimated to be of the order of 20 to 30 years (Anderson $e t$ al., 2008; Paterson, 2004).

The structures and relationships that affect the distribution of risks across the industry and decision-making within and across organizational boundaries are key to the adaptive capacity of viticulture and the winemaking industry as a whole. Many of these structures and relationships have been transformed by globalization of the wine industry, including the creation of new regions of production and consumption, as well as the growing involvement of multinational companies throughout the supply chain (Anderson et al., 2003).

Nevertheless, the perception of wine and winemaking as intimately related to the provenance of grape cultivation is not entirely without justification and there remains a strong regional identity to much of the industry, most evident in the reputation of certain winemaking regions 
and localities. If the relationship between provenance and quality has weakened over recent decades (Moran, 1993; Giraud-Heraud et al., 1998; Vaudour, 2002), it remains widely used by consumers to differentiate between wines not only from traditional European winemaking regions, but also from those regions that pioneered the use of alternative indicators of quality such as cultivars and wine brands to shape consumer expectations (Bailly, 2000; Schamel \& Anderson 2003).

\section{Provenance and adaptive decision-making}

The importance of provenance to many wines and winemaking regions, and the methods used to maintain its value as an indicator of wine character and quality, provides an example of the complex way in which regulatory and institutional structures (or the lack of them) can affect decision-making and the adaptive capacity of the industry.

The association of provenance with wines of particular quality and character represents considerable investments not only to individual businesses but also to regional industries. Like physical common-pool resources, provenance risks being exploited and reduced in value if the quality or type of products fails to accord with expectations (Patchell, 2008; Ostrom, 2015). Whereas such concerns have been strongest in the long-established European winemaking regions, similar concerns have been expressed about areas central to the expansion and reputation of more recent winemaking nations, for example Napa Valley in the USA and Marlborough Sauvignon Blanc in the New Zealand wine industry (Hayward \& Lewis, 2008; Overton, 2010). 
Protection of this common 'resource' is often provided by regulations governing the use of geographical indicators of provenance, which now exist in most major winemaking nations (Banks \& Sharpe, 2006; Josling, 2006; Overton \& Heitger, 2008). The most elaborate of such systems remains the French AOC system, established in 1935, that seeks to ensure provenance is a coherent indicator of wine value and character by not only restricting grape provenance, but also the cultivars, methods of production and yields for particular appellations. The restrictions imposed by the French AOC system, however, can impede the ability of the industry to adapt to future climate change (Lereboullet et al., 2013b) by requiring the cultivation of vine cultivars in locations of declining suitability, and by impeding the adoption of innovative viticulture and winemaking practices. The fine geographical scale at which many appellations are defined can augment the economic impact of extreme weather events (Belliveau et al., 2006), while the implications for product value create major land price differentials within and between viticulture regions that inhibit changes in land use. Although producers may opt out of the AOC system - and France has seen significant growth in premium wines not belonging to reputed AOC designations (Garcia-Parpet, 2008) - the risks of such a strategy to market value are major deterrents for established producers.

Critiques of the AOC and similar regulatory systems can reflect an opposition to market regulation in principle. Unregulated markets, however, offer no guarantee of more adaptive decision-making. A relatively small number of grape cultivars dominate the global wine market (This et al., 2006) which inhibits the adoption of less familiar cultivars better suited to emerging climatic conditions (Shaw, 1999; Belliveau et al., 2006; Hope-Ross et al., 2006; Holland \& Smit, 2010) irrespective of regulatory barriers. 
Likewise, there can also be an implicit favouring of individual businesses and producers as the optimal scale for adaptive decision-making. Yet adaptive and maladaptive strategies can be realized at many different scales beyond the individual actor or organisation if there is the motivation and mechanisms available for collective decision-making (Eakin \& Patt, 2011). The importance of provenance and the systems that protect geographical indicators of origin can, at least in principal, provide the regulatory tools and institutions whereby collective strategies can be implanted at a regional scale across the production chain (Patchell, 2008). Regional trade associations, government structures and other supporting organisations and industry bodies might similarly provide mechanisms to facilitate decision-making and innovation, and (re)distribute the benefits and risks of adaptive strategies (Porter, 1998; Giuliani et al., 2011).

New regions and participants to the industry are the most likely to view the removal of institutional frameworks and regulations governing provenance as facilitating the innovation required for successful adaptation. Established businesses and regions are more likely to see the same 'de-regulation' as undermining decades of investment and the preservation of regional qualities and reputations as essential to adaptation. In both cases, these views will influence perceptions about the desirability of different adaptive strategies. The protection of provenance as an indicator of wine quality can therefore inhibit innovation and adaptation within the industry, but recognition of provenance as a communal asset provides an incentive for decision-making to extend beyond individual businesses and organisations, thereby permitting the realization of a wider range of adaptive strategies. 
The concept of wine quality, of which provenance acts as an indicator, is itself subject to evolution and this in turn will change the requirements of viticulture. 'Consumer naivety', particularly in the rapidly growing Asian markets (Lee, 2009) can reinforce the value of traditional indicators of quality, such as provenance, and of alternative indicators such as the quality ratings of a select few global wine critics (Gibbs et al., 2009). Equally, however, the development of new markets may hasten an evolution in consumer tastes and transform perceptions of wine quality, which in turn will determine the requirements of viticulture under changing climate conditions.

\section{Lessons from the vineyard}

Viticulture provides not only an example of an agriculture that is highly sensitive to changes in climate conditions, but also of a system on which the impacts of climate change are wideranging, and the capacity for adaptation subject to global and regional, social-economic and cultural determinants. But what lessons can be drawn that might be applied to other systems vulnerable to future climate change?

\section{Capturing the impacts of climate change}

Firstly, many of the potential impacts of climate change on the yield, timing and quality of vineyard harvests occur at high temporal and spatial resolutions that have not been well captured by the metrics and models used to assess climate change impacts. Viticulture therefore illustrates the widely debated effects of a mismatch between the spatial resolution at which climate data are collected and that experienced by organisms (Araújo \& New, 2007; Lobell et al., 2006; Wiens et al., 2009; Willis \& Bhagwat, 2009; Potter et al., 2013; Bennie et al., 2014; Harwood et al., 2014). Just as vineyards prevail in unsuitable climates through association with distinctive topographical niches, so too the exposure of other species to the 
effects of climate change can be buffered by a combination of fine-scale microclimate variation and changes in habitat association (Suggitt et al., 2011; Maclean et al., 2015). The temporal resolution of data affects the capacity to capture climate change impacts relating to a change in weather conditions at key stages of species development (Wilson et al., 2007; Morin \& Chuine, 2014).

Secondly, viticulture illustrates that the projections of geographical shifts in crop suitability or species ranges resulting from climate change, risk undervaluing the potential of in-situ management and fine-scale habitat variability to reduce impacts, not only on crop systems but also on natural and semi-natural ecosystems (Greenwood et al., 2016). Quantitative information about natural variation and the capacity to manipulate local conditions is required if the potential of in-situ management and adaptation strategies is to be incorporated into impact studies.

Thirdly, there is a need for greater empirical testing and comparison of impact models in terms of their choice of impact metrics and the reliability of models (Rotter et al., 2011). Doubts about the reliability of time series analyses that underpin many models of grapevine phenology also apply to other plant species (Wolkovich et al., 2012). More generally, it is important to demonstrate the limiting factors on species distribution, crop yield or other key characteristics that operate at different scales and resolutions.

Developments in data provision, analytical tools and computing capacity offer an opportunity to widen the application of dynamic crop models in impact studies on viticulture. Stochastic weather generators (Semenov \& Barrow, 1997) have been used as a climate downscaling technique in studies on viticulture (Moriondo et al., 2011), but their capacity to model unique time series of daily or hourly weather under future climate scenarios also permits study of 
changes to risks associated with the timing and frequency of weather events at key stages of development (Mosedale et al., 2015).

Wider application of dynamic models is to be expected (Cola et al., 2014) but requires adopting the lessons learnt from other crop systems, including developing methods for estimating uncertainty, the use of model ensembles, and methods for field-level simulations to account for variation in landscape and management across larger areas (Rotter et al., 2011, Palosuo et al. 2011). The integration of statistical and dynamic modelling approaches may well prove the most fruitful approach. Statistical models can help inform about the scale of application of dynamic models (Challinor et al. 2003), or distinct statistical models can be applied as a function of phenological modelling (Landau et al. 2000). Dynamic models could allow the mapping of cultivar suitability for different cultivars, not just on thermal basis, but also on their tolerance to different stress factors (Costa et al 2015).

A combined approach can also be applied to downscaling weather data to higher levels of resolution. Regional weather station and remote sensing data has been used to construct physical variables capturing landscape effects that are used to calibrate a statistical model of fine-scale regional variations ( $<100$ metres resolution) in temperature for a variety of landscapes (Bennie et al., 2008; Hannah et al., 2014; Kearney et al., 2014; Maclean et al., 2016). The ability of such tools to simulate local conditions can be combined with grapevine canopy models (Louarn et al., 2008; López-Lozano et al., 2011) and radiative transfer models (Chelle \& Andrieu, 1998) to simulate irradiance levels and other conditions for whole canopies. Such dynamic model systems offer the potential to calculate the primary production of whole crop systems (Prieto et al., 2012) under different climatic conditions, integrate the effects of future increases in CO2 concentrations on grapevine growth (Bindi et al., 2001; Tognetti et al., 2005) and assess the adaptive capacity of changes in crop management. 


\section{Informing decision-making}

The provision of climate change information should be driven by the needs of decisionmakers and not solely by the availability of improved data and models. Climate change affects exposure to multiple risks, the relative importance of which varies between viticulture regions. The risk of frost or poor flowering conditions may be negligible for most regions but critical to a few for which climate change information will lack relevance if these risks are ignored.

Studies of perceptions and attitudes can help inform impact studies, but it is direct participation of the users of information in the 'co-production' (Lemos \& Morehouse, 2005; Pohl et al., 2010) of climate change information that is most effective in ensuring relevance. Several regional studies have demonstrated how engagement with local practitioners can help researchers identify key impacts of climate change, as well as better understanding the wider risk context and factors affecting adaptation options (Belliveau et al., 2006; Holland \& Smit, 2010; Lereboullet et al., 2013a). The transparency of the methods and metrics used is also important. Describing the effects of climate change on vintage ratings or harvest prices appears to have direct financial relevance to decision-makers within the industry, but the opacity of the models used can render the results less informative than simple climate-related metrics and risks that can be readily interpreted. Industry knowledge and expertise can often be exploited by the way in which information is presented such as citing existing climate analogues to future conditions (Dunn et al., 2015).

Impact studies also lack salience if there is a mismatch between the resolution of information provided and the scale of effective adaptation and decision-making (Cash et al., 2006; Bodin et al., 2014). Many impact studies do not capture the potential of adaptive strategies that exploit variation in local climatic conditions or grapevine phenology. Likewise the scope of 
impact studies often reflects the geography of bioclimatic factors rather than the geography of decision-making mechanisms, regulatory systems or indicators of product value. In the case of viticulture, the identification of effective decision-making mechanisms within the industry - whether at the level of individual businesses or co-operatives, regional appellations or national regulatory or trade bodies - can help to provide more useful information of appropriate resolution and scope.

Finally, viticulture provides a reminder that the adaptive capacity of agricultural systems is contingent upon the value attributed to inherent characteristics of the system and the products they provide. The high value of premium wines permits a wider range of adaptive strategies for viticulture than would be feasible for lower value crops. What we value, however, is subject to change. Many grape qualities required for the production of highly valued wines can be defined, but both the types of wines that are most valued and the grape qualities required to produce them are not fixed over time. Rather they emerge from the combination of biophysical and technical characteristics with cultural expectations, social and economic factors. Likewise, the values we attribute to other natural and managed systems, are neither constant nor ubiquitous, but shaped by culture and values whose evolution will affect the capacity and incentives to improve the resilience of these systems.

\section{Conclusion}

Improved analysis of the impacts of climate change and the mechanisms of adaptation will benefit but will not of itself ensure adaptive decision-making. Viticulture illustrates how agreement about the biophysical consequences of climate change does not imply agreement about the need or strategy of adaptation.

Impact studies have tended to focus on large-scale, transformative changes by which the 
industry may adapt to climate change - strategies that imply significant and unequal risks to industry participants. As a crop system, however, viticulture has proved viable across a wide range of climatic conditions through the adaptation of vineyard locations, establishment, management and the style of wine produced. The same characteristics offer the potential for reducing exposure and sensitivity to the impacts of future climate change.

Improvements to the adaptive capacity of the industry depend not only upon decisions by individual participants and organisations, but on a capacity for collective adaptive decisionmaking across organisational boundaries. Climate change is only one of many factors affecting the risk environment of participants in the winemaking industry - an environment that is continually evolving from changes to the global wine market, regulatory regimes and continued developments in technology and consumer demands. Ultimately the viability of viticulture under future climate change scenarios is a cultural decision set within a context of changing socio-economic and biological viability.

\section{Acknowledgements}

We are grateful for the constructive comments and suggestions of both reviewers of the original text.

\section{References}

Adger WN, Brown K, Fairbrass J, Jordan A, Paavola J, Rosendo S, Seyfang G (2003) Governance for sustainability: towards a "thick" analysis of environmental decisionmaking. Environment and Planning A, 35, 1095-1110.

Adger WN, Dessai S, Goulden M et al. (2008) Are there social limits to adaptation to climate change? Climatic Change, 93, 335-354.

Alonso AD, O’Neill MA (2011) Climate change from the perspective of Spanish wine 
growers: a three-region study. British Food Journal, 113, 205-221.

Amerine MA, Winkler AJ (1944) Composition and Quality of Musts and Wines of California Grapes. Hilgardia, 15, 493-675.

Anderson K, Nelgen S (2011) Global Wine Markets, 1961 to 2009: A statistical compendium. University of Adelaide Press.

Anderson K, Norman D, Wittwer G (2003) Globalisation of the World's Wine Markets. World Economy, 26, 659-687.

Anderson K, Findlay C, Fuentes S, Tyerman S (2008) Viticulture, wine and climate change. Report commissioned for the Garnaut Climate Change Review. Available at: http://www.garnautreview.org.au/CA25734E0016A131/WebObj/01HViticulture/\$File/01-H\%20Viticulture.pdf

Araújo MB, New M (2007) Ensemble forecasting of species distributions. Trends in Ecology \& Evolution, 22, 42-47.

Ashcroft MB, Chisholm LA, French KO (2009) Climate change at the landscape scale: predicting fine-grained spatial heterogeneity in warming and potential refugia for vegetation. Global Change Biology, 15, 656-667.

Asseng S, Ewert F, Rosezweig C, et al. (2013) Uncertainty in simulating wheat yields under climate change. Nature Climate Change, 3, 827-832.

Bailly AS (2000) Le temps des cépages. Du terroir au système-monde / Local or global strategies for wine-growing. Annales de Géographie, 109, 516-524.

Banks G, Sharpe S (2006) Wine, regions and the geographic imperative: The Coonawarra example. New Zealand Geographer, 62, 173-184.

Barnuud NN, Zerihun A, Mpelasoka F, Gibberd M, Bates B (2013) Responses of grape berry anthocyanin and titratable acidity to the projected climate change across the Western Australian wine regions. International Journal of Biometeorology, 1-15. 
Belliveau S, Smit B, Bradshaw B (2006) Multiple exposures and dynamic vulnerability: Evidence from the grape industry in the Okanagan Valley, Canada. Global Environmental Change, 16, 364-378.

Ben Asher J, Tsuyuki I, Bravdo B-A, Sagih M (2006) Irrigation of grapevines with saline water: I. Leaf area index, stomatal conductance, transpiration and photosynthesis. Agricultural Water Management, 83, 13-21.

Bennie J, Huntley B, Wiltshire A, Hill MO, Baxter R (2008) Slope, aspect and climate: Spatially explicit and implicit models of topographic microclimate in chalk grassland. Ecological Modelling, 216, 47-59.

Bennie J, Wilson RJ, Maclean IMD, Suggitt AJ (2014) Seeing the woods for the trees - when is microclimate important in species distribution models? Global Change Biology, 20, 2699-2700.

Bindi M, Fibbi L, Miglietta F (2001) Free Air CO2 Enrichment (FACE) of grapevine (Vitis vinifera L.): II. Growth and quality of grape and wine in response to elevated $\mathrm{CO} 2$ concentrations. European Journal of Agronomy, 14, 145-155.

Bindi M, Gozzini B, Orlandini S, Miglietta F (1996) Modelling the impact of future climate scenarios on yield and yield variability of grapevine. Climate Research, 7, 213-224.

de Blij HJ (1983) Geography of Viticulture: Rationale and Resource. Journal of Geography, $82,112-121$.

Bock A, Sparks T, Estrella N, Menzel A (2011) Changes in the phenology and composition of wine from Franconia, Germany. Climate Research, 50, 69-81.

Bodin öRjan, Crona B, Thyresson M, Golz A-L, Tengö M (2014) Conservation Success as a Function of Good Alignment of Social and Ecological Structures and Processes: Social-Ecological Fit and Conservation. Conservation Biology, 28, 1371-1379.

Bonada M, Sadras VO (2015) Review: critical appraisal of methods to investigate the effect 
of temperature on grapevine berry composition. Australian Journal of Grape and Wine Research, 21, 1-17.

Bonnardot V, Cautenet S (2009) Mesoscale Atmospheric Modeling Using a High Horizontal Grid Resolution over a Complex Coastal Terrain and a Wine Region of South Africa. Journal of Applied Meteorology \& Climatology, 48, 330-348.

Bonnardot V, Planchon O, Cautenet S (2005) Sea breeze development under an offshore synoptic wind in the South-Western Cape and implications for the Stellenbosch wineproducing area. Theoretical and Applied Climatology, 81, 203-218.

Bonnefoy C, Quenol H, Bonnardot V, Barbeau G, Madelin M, Planchon O, Neethling E (2013) Temporal and spatial analyses of temperature in a French wine-producing area: the Loire Valley. International Journal of Climatology, 33, 1849-1862.

Bowers J, Boursiquot J-M, This P, Chu K, Johansson H, Meredith C (1999) Historical Genetics: The Parentage of Chardonnay, Gamay, and Other Wine Grapes of Northeastern France. Science, 285, 1562-1565.

Brisson N, Justes CG, Roche et al. (2003) An overview of the crop model STICS. An overview of the crop model stics. European Journal of Agronomy, 18, 309-332.

Brisson N, Levrault F (2010) Climate change, agriculture and forests in France: simulations of the impacts on the main species. The Green Book of the CLIMATOR project (2007-2010). ADEME, INRA, France.

Bryant L, Garnham B (2013) Beyond discourses of drought: The micro-politics of the wine industry and farmer distress. Journal of Rural Studies, 32, 1-9.

Burrell J, Brooke T, Beckwith R (2004) Vineyard computing: sensor networks in agricultural production. Pervasive Computing, 3, 38-45.

Caffarra A, Eccel E (2010) Increasing the robustness of phenological models for Vitis vinifera cv. Chardonnay. International Journal of Biometeorology, 54, 255-267. 
Caffarra A, Eccel E (2011) Projecting the impacts of climate change on the phenology of grapevine in a mountain area. Australian Journal of Grape and Wine Research, 17, $\underline{52-61 .}$

Caffarra A, Rinaldi M, Eccel E, Rossi V, Pertot I (2012) Modelling the impact of climate change on the interaction between grapevine and its pests and pathogens: European grapevine moth and powdery mildew. Agriculture, Ecosystems \& Environment, 148, 89-101.

Calonnec A, Cartolaro P, Naulin J-M, Bailey D, Langlais M (2008) A host-pathogen simulation model: powdery mildew of grapevine. Plant Pathology, 57, 493-508.

Cash DW, Adger WN, Berkes F, Garden P, Lebel L, Olsson P, Pritchard L, Yound O (2006) $\underline{\text { Scale and cross-scale dynamics: governance and information in a multilevel world. }}$ Ecology and society, 11, 8.

Castellano S, Scarascia Mugnozza G, Russo G, Briassoulis D, Mistriotis A, Hemming S, Waaijenberg D (2008) Plastic Nets in Agriculture: A General Review of Types and Applications. Applied engineering in agriculture. 24, 799-808.

Celette F, Findeling A, Gary C (2009) Competition for nitrogen in an unfertilized intercropping system: The case of an association of grapevine and grass cover in a Mediterranean climate. European Journal of Agronomy, 30, 41-51.

Celette F, Ripoch A, Gary C. (2010) WaLIS-A simple model to simulate water partitioning in a crop association: The example of an intercropped vineyard. Agricultural Water Management, 97, 1749-1759.

Centonze AL (2010) Transitional Cluster Development: A Case Study From the New York Wine Industry. Economic Development Quarterly. 24, 251-260.

Challinor AJ, Slingo JM, Wheeler TR, Crauford PQ, Grimes DIF (2003) Toward a Combined Seasonal Weather and Crop Productivity Forecasting System: Determination of the 
Working Spatial Scale. Journal of Applied Meteorology, 42, 175-192.

Challinor AJ, Parkes B, Ramirez-Villegas J (2015) Crop yield response to climate change varies with cropping intensity. Global Change Biology, 21, 1679-1688.

Chelle M, Andrieu B (1998) The nested radiosity model for the distribution of light within plant canopies. Ecological Modelling, 111, 75-91.

Chuine I, Kramer K, Hänninen H (2003) Plant Development Models. In: Phenology: An Integrative Environmental Science (ed Schwartz MD), pp. 217-235. Springer Netherlands.

Chuine I, Yiou P, Viovy N, Seguin B, Daux V, Ladurie ELR (2004) Historical phenology: Grape ripening as a past climate indicator. Nature, 432, 289-290.

Cola G, Mariani L, Salinari F, Civardi S, Bernizzoni F, Gatti M, Poni S (2014) Description and testing of a weather-based model for predicting phenology, canopy development and source-sink balance in Vitis vinifera L. cv. Barbera. Agricultural and Forest Meteorology, 184, 117-136.

Conceição MA, Tonietto J (2005) Climatic potential for wine grape production in the tropical north region of Minas Gerais State, Brazil. Revista Brasileira de Fruticultura, 27, 404-407.

de Cortazar-Atauri IG (2006) Adaptation du modèle STICS à la vigne (Vitis vinifera L.). Utilisation dans le cadre d'une étude d'impact du changement climatique à l'échelle de la France. PhD thesis, Montpellier, France.

de Cortázar-Atauri I, Brisson N, Gaudilere J-P (2009) Performance of several models for predicting budburst date of grapevine (Vitis vinifera L.). International Journal of Biometeorology, 53, 317-326.

Costa R, Fraga H, Malheiro AC, Santos JA (2015) Application of crop modelling to portuguese viticulture: implementation and added-values for strategic planning. 
Ciência e Técnica Vitivinícola, 30, 29-42.

Downey MO, Dokoozlian NK, Krstic MP (2006) Cultural Practice and Environmental Impacts on the Flavonoid Composition of Grapes and Wine: A Review of Recent Research. American Journal of Enology and Viticulture, 57, 257-268.

Due G, Morris M, Pattison S, Coombe BG (1993) Modelling grapevine phenology against weather: Considerations based on a large data set. Agricultural and Forest Meteorology, 65, 91-106.

Dry PR (2000) Canopy management for fruitfulness. Australian Journal of Grape and Wine Research, 6, 109-115.

Duchene E, Schneider C (2005) Grapevine and climatic changes: a glance at the situation in Alsace. Agronomy for Sustainable Development, 25, 93-99.

Duchene E, Huard F, Dumas V, Schneider C, Merdinoglu D (2010) The challenge of adapting grapevine varieties to climate change. Climate Research, 41, 193-204.

Dunn MR, Lindesay JA, Howden M (2015) Spatial and temporal scales of future climate information for climate change adaptation in viticulture: a case study of User needs in the Australian winegrape sector. Australian Journal of Grape and Wine Research, 21, 226-239.

Eakin HC, Patt A (2011) Are adaptation studies effective, and what can enhance their practical impact? Wiley Interdisciplinary Reviews: Climate Change, 2, 141-153.

Eitzinger J, Thaler S, Schmid E et al. (2013) Sensitivities of crop models to extreme weather conditions during flowering period demonstrated for maize and winter wheat in Austria. The Journal of Agricultural Science, 151, 813-835.

Ewert F, Rodriguez D, Jamieson P et al. (2002) Effects of elevated CO2 and drought on wheat: testing crop simulation models for different experimental and climatic conditions. Agriculture, Ecosystems \& Environment, 93, 249-266. 
Fila G, Gardiman M, Belvini P, Meggio F, Pitacco A (2014) A comparison of different modelling solutions for studying grapevine phenology under present and future climate scenarios. Agricultural and Forest Meteorology, 195-196, 192-205.

Fleming A, Rickards L, Dowd AM (2015a) Understanding convergence and divergence in the framing of climate change responses: An analysis of two wine companies. Environmental Science \& Policy, 51, 202-214.

Fleming A, Park SE, Marshall NA (2015b) Enhancing adaptation outcomes for transformation: climate change in the Australian wine industry. Journal of Wine Research, 26, 99-114.

Fraga H, Malheiro AC, Moutinhp-Pereira J, Santos JA (2012) An overview of climate change impacts on European viticulture. Food and Energy Security, 1, 94-110.

Fraga H, Malheiro AC, Moutinho-Pereira J, Cardoso R, Soares PMM, Cancela JJ, Pinto JG, $\underline{\text { Santos JA (2014a) Integrated analysis of climate, soil, topography and vegetative }}$ growth in Iberian viticultural regions. PLOS One, 9(9): e108078.

Fraga H, Malheiro AC, Moutinho-Pereira J, Jones GV, Alves F, Pinto JG, Santos JA (2014b) Very high resolution bioclimatic zoning of Portuguese wine regions: present and future scenarios. Regional Environmental Change, 14, 295-306.

Fraga H, Malheiro AC, Moutinhp-Pereira J, Santos JA (2014c) Climate factors driving wine production in the Portugese Minho region. Agricultural and Forest Meteorology, 185, 26-36.

Fraga H, Santos JA, Malheiro AC, Oliveira AA, Moutinho-Pereira J, Jones GV (2015) Climatic suitability of Portuguese grapevine varieties and climate change adaptation. International Journal of Climatology, 36:1-12.

Fraga H, Santos JA, Moutinho-Pereira J, Carlos C, Silvestre J, Eiras-Dias J,Mota T, Malheiro AC, (2016) Statistical modelling of grapevine phenology in Portuguese wine regions: 
observed trends and climate change projections. The Journal of Agricultural Science, $154,795-811$.

Friend AP, Trought MCT (2007) Delayed winter spur-pruning in New Zealand can alter yield components of Merlot grapevines. Australian Journal of Grape and Wine Research, $13,157-164$.

Francesca S, Simona G, Nicola TF, Andrea R, Vittorio R, Federico S, Rosenzweig C, Lodovica GM (2006) Downy mildew (Plasmopara viticola) epidemics on grapevine under climate change. Global Change Biology, 12, 1299-1307.

Galbreath J (2014) Climate Change Response: Evidence from the Margaret River Wine Region of Australia. Business Strategy and the Environment, 23, 89-104.

Garcia-Parpet M-F (2008) Markets, prices and symbolic value: grands crus and the challenges of global markets. International Review of Sociology, 18, 237-252.

Gibbs M, Tapia M, Warzynski F (2009) Globalization, Superstars, and Reputation: Theory \& Evidence from the Wine Industry. Journal of Wine Economics, 4, 46-61.

Giraud-Heraud E, Soler LG, Steinmetz S, Tanguy H (1998) Is the interprofessional regulation in the vitivinicultural sector economically founded ? Bulletin de l'OIV, 71, 10591084.

Giuliani E, Morrison A, Rabellotti R (2011) Innovation and technological catch-up in the wine industry: an introduction. In: Innovation and Technological Catch-Up: The Changing Geography of Wine Production, 1-16, Edward Elgar Publishing.

Gladstones J (1992) Viticulture and environment. Winetitles, Adelaide.

Glenn DM, Cooley N, Walker R, Clingeleffer P, Shellie K (2010) Impact of Kaolin Particle Film and Water Deficit on Wine Grape Water Use Efficiency and Plant Water Relations. HortScience, 45, 1178-1187.

Godwin DC, White RJG, Sommer KJ, Walker RR, Goodwin I, Clingeleffer PR (2002) 
VineLOGIC - a model of grapevine growth, development and water use. In:

C.Dundon, R.Hamilton, R.Johnstone and S.Partridge (Eds), Managing Water.

(Australian Society of Viticulture and Oenology Inc.: Adelaide ) pp. 46-50.

Gonzalez-Barreiro C, Rial-Otero R, Cancho-Grande B, Simal-Gándara J (2013) Wine Aroma Compounds in Grapes: A Critical Review. Critical Reviews in Food Science and Nutrition, 55, 202-218.

Greenwood O, Mossman HL, Suggitt AJ, Curtis RJ, Maclean IMD (2016) Using in situ management to conserve biodiversity under climate change. Journal of Applied Ecology, doi: 10.1111/1365-2664.12602.

Greer DH, Weedon MM, Weston C (2011) Reductions in biomass accumulation, photosynthesis in situ and net carbon balance are the costs of protecting Vitis vinifera "Semillon" grapevines from heat stress with shade covering. AoB Plants, 2011, plr023.

Grifoni D, Mancini M, Maracchi G, Orlandini S, Zipoli G (2006) Analysis of Italian Wine Quality Using Freely Available Meteorological Information. American Journal of Enology and Viticulture, 57, 339-346.

Grifoni D, Carreras G, Zipoli G, Sabatini F, Dalla Marta, A Orlandini S (2008) Row orientation effect on UV-B, UV-A and PAR solar irradiation components in vineyards at Tuscany, Italy. International Journal of Biometeorology, 52, 755-763

Grothmann T, Patt A (2005) Adaptive capacity and human cognition: The process of individual adaptation to climate change. Global Environmental Change, 15, 199-213.

Gu S (2015) Growing degree hours - a simple, accurate, and precise protocol to approximate growing heat summation for grapevines. Internation Journal of Biometeorology, doi 10.1007/s00484-015-1105-8.

Guisan A, Thuiller W (2005) Predicting species distribution: offering more than simple 
habitat models. Ecology Letters, 8, 993-1009.

Hall A, Jones GV (2009) Effect of potential atmospheric warming on temperature-based indices describing Australian winegrape growing conditions. Australian Journal of Grape and Wine Research, 15, 97-119.

Hall A, Lamb DW, Holzapfel B, Louis J (2002) Optical remote sensing applications in viticulture - a review. Australian Journal of Grape and Wine Research, 8, 36-47.

Hannah L, Roehrdanz PR, Ikegami M et al. (2013) Climate change, wine, and conservation. Proceedings of the National Academy of Sciences, 110, 6907-6912.

$\underline{\text { Hannah L, Flint L, Syphard AD, Moritz MA, Buckley LB, McCullough IM (2014) Fine-grain }}$ modeling of species' response to climate change: holdouts, stepping-stones, and microrefugia. Trends in Ecology \& Evolution, 29, 390-397.

Harwood TD, Mokanny K, Paini DR (2014) Microclimate is integral to the modelling of plant responses to macroclimate. Proceedings of the National Academy of Sciences, 111, E1164-E1165.

Haselgrove L, Botting D, van Heeswijck R, Høj PB, Dry PR, Ford C, Iland PG (2000) Canopy microclimate and berry composition: The effect of bunch exposure on the phenolic composition of Vitis vinifera L cv. Shiraz grape berries. Australian Journal of Grape and Wine Research, 6, 141-149.

Haylock MR, Hofstra N, Klein Tank AMG, Klok EJ, Jones PD, New M (2008) A European daily high-resolution gridded data set of surface temperature and precipitation for 1950-2006. Journal of Geophysical Research: Atmospheres, 113, D20119.

Hayward D, Lewis N (2008) Regional dynamics in the globalising wine industry: the case of Marlborough, New Zealand. Geographical Journal, 174, 124-137.

Hewitson BC, Daron J, Crane RG, Zermoglio MF, Jack C (2014) Interrogating empiricalstatistical downscaling. Climatic Change, 122, 539-554. 
Hijmans RJ, Cameron SE, Parra JL, Jones PG, Jarvis A (2005) Very high resolution interpolated climate surfaces for global land areas. International Journal of Climatology, 25, 1965-1978.

Hijmans RJ, Graham CH (2006) The ability of climate envelope models to predict the effect of climate change on species distributions. Global Change Biology, 12, 2272-2281.

Holland T, Smit B (2010) Climate Change and the Wine Industry: Current Research Themes and New Directions. Journal of Wine Research, 21, 125-136.

Howden SM, Soussana J-F, Tubiello FN, Chhetri N, Dunlop M, Meinke H (2007) Adapting agriculture to climate change. Proceedings of the National Academy of Sciences, 104, 19691-19696.

Hope-Ross P, Statistics Canada, Business and Trade Statistics Field (2006) From the vine to the glass Canada's grape and wine industry. Statistics Canada, Ottawa.

Hussein M, Cholette S, Castaldi RM (2008) An Analysis of Globalization Forces in the Wine Industry. Journal of Global Marketing, 21, 33-47.

Jackson DI, Lombard PB (1993) Environmental and Management Practices Affecting Grape Composition and Wine Quality - A Review. American Journal of Enology and Viticulture, 44, 409-430.

Jones GV, Davis RE (2000) Climate Influences on Grapevine Phenology, Grape

Composition, and Wine Production and Quality for Bordeaux, France. American Journal of Enology and Viticulture, 51, 249-261.

Jones GV, White MA, Cooper OR, Storchmann K (2005) Climate Change and Global Wine Quality. Climatic Change, 73, 319-343.

Jones GV (2006) Climate and Terroir: Impacts of climate variability and change on wine. In: Fine Wine and Terroir - The Geoscience Perspective (eds Macqueen RW, Meinert LD), pp 1-14, Geoscience Canada Reprint Series 9, 203-217, Geological Association 
of Canada, St John's Newfoundland.

Josling T (2006) The War on Terroir: Geographical Indications as a Transatlantic Trade Conflict. Journal of Agricultural Economics, 57, 337-363.

Kast WK, Rupp D (2009) Effects of climatic change on phenology and ripening conditions of grapevine. Mitteilungen Klosterneuburg, Rebe und Wein, Obstbau und Früchteverwertung, 59, 3-7.

Kearney M, Porter W (2009) Mechanistic niche modelling: combining physiological and spatial data to predict species' ranges. Ecology Letters, 12, 334-350.

Kearney MR, Shamakhy A, Tingley R, Karoly DJ, Hoffmann AA, Briggs PR, Porter WP (2014) Microclimate modelling at macro scales: a test of a general microclimate model integrated with gridded continental-scale soil and weather data. Methods in Ecology and Evolution, 5, 273-286.

Keller M (2010) Managing grapevines to optimise fruit development in a challenging environment: a climate change primer for viticulturists. Australian Journal of Grape and Wine Research, 16, 56-69.

Keller M, Koblet W (1995) Dry matter and leaf area partitioning, bud fertility and second season growth of 1Ttis vinifera L. : Responses to nitrogen supply and limiting irradiance. Vitis, 43, 77-83.

Kenny GJ, Harrison PA (1992) The effects of climate variability and change on grape suitability in Europe. Journal of Wine Research, 3, 163-183.

Kiem AS, Austin EK (2013) Drought and the future of rural communities: Opportunities and challenges for climate change adaptation in regional Victoria, Australia. Global Environmental Change, 23, 1307-1316.

Kliewer WM (1977) Effect of High Temperatures during the Bloom-Set Period on Fruit-Set, Ovule Fertility, and Berry Growth of Several Grape Cultivars. American Journal of 
Enology and Viticulture, 28, 215-222.

Koblet W (1966) Berry set of grape vines related to shoot treatments and climatic factors.

Doctoral thesis, Zurich. http://e-collection.library.ethz.ch/eserv/eth:32946/eth-3294601.pdf

Landau S, Mitchell RAC, Barnett V, Colls JJ, Craigon J, Payne RW (2000) A parsimonious, multiple-regression model of wheat yield response to environment. Agricultural and Forest Meteorology, 101, 151-166.

Lee K (2009) Is a glass of Merlot the symbol of globalization?: An examination of the impacts of globalization on wine consumption in Asia. International Journal of Wine Business Research, 21, 258-266.

van Leeuwen C, Friant P, Choné X, Tregoat O, Koundouras S, Dubourdieu D (2004)

Influence of Climate, Soil, and Cultivar on Terroir. American Journal of Enology and Viticulture, 55, 207-217.

van Leeuwen C, Seguin G (2006) The concept of terroir in viticulture. Journal of Wine Research, 17, 1-10.

van Leeuwen C, Schultz HR, Garcia de Cortazar-Atauri I et al. (2013) Why climate change will not dramatically decrease viticultural suitability in main wine-producing areas by 2050. Proceedings of the National Academy of Sciences, 110, E3051-E3052.

Lemos MC, Morehouse BJ (2005) The co-production of science and policy in integrated climate assessments. Global Environmental Change, 15, 57-68.

Lemos MC, Kirchhoff CJ, Ramprasad V (2012) Narrowing the climate information usability gap. Nature Climate Change, 2, 789-794.

Lereboullet A-L, Beltrando G, Bardsley DK (2013a) Socio-ecological adaptation to climate change: A comparative case study from the Mediterranean wine industry in France and Australia. Agriculture, Ecosystems \& Environment, 164, 273-285. 
Lereboullet A-L, Beltrando G, Bardsley DK, Rouvellac E (2013b) The viticultural system and climate change: coping with long-term trends in temperature and rainfall in Roussillon, France. Regional Environmental Change, 1-16.

Lobell DB, Field CB, Cahill KN, Bonfils C (2006) Impacts of future climate change on California perennial crop yields: Model projections with climate and crop uncertainties. Agricultural and Forest Meteorology, 141, 208-218.

López-Lozano R, Baret F, Garcia de Cortázar Atauri I, Lebon E, Tisseyre B (2011) 2D approximation of realistic 3D vineyard row canopy representation for light interception (fIPAR) and light intensity distribution on leaves (LIDIL). European Journal of Agronomy, 35, 171-183.

Louarn G, Lecoeur J, Lebon E (2008) A Three-dimensional Statistical Reconstruction Model of Grapevine (Vitis vinifera) Simulating Canopy Structure Variability within and between Cultivar/Training System Pairs. Annals of Botany, 101, 1167-1184.

Lough JM, Wigley TML, Palutikof JP (1983) Climate and Climate Impact Scenarios for Europe in Warmer World. Journal of Climate and Applied Meteorology, 22, 16731684.

Lund ST, Bohlmann J (2006) The Molecular Basis for Wine Grape Quality-A Volatile Subject. Science, 311, 804-805.

Maclean IMD, Hopkins JJ, Bennie J, Lawson CR, Wilson RJ (2015) Microclimates buffer the responses of plant communities to climate change. Global Ecology and Biogeography, 24, 1340-1350.

Maclean IMD, Suggitt AJ, Wilson RJ , Duffy JP, Bennie JJ (2016) Fine-scale climate change: modelling spatial variation in biologically meaningful rates of warming. Global Change Biology, d.o.i. 10.1111/gcb.13343.

Madelin M, Beltrando G (2005) Spatial interpolation-based mapping of the spring frost 
hazard in the Champagne vineyards. Meteorological Applications, 12, 51-56.

Malheiro AC, Campos R, Fraga H, Eiras-Dias J, Silvestre J, Santos JA (2013) Winegrape

Phenology and Temperature Relationships in the Lisbon Wine Region, Portugal.

Journal International Des Sciences De La Vigne Et Du Vin, 47, 287-299.

Marsal J, Utset A (2008) Vineyard full-irrigation requirements under climate change

scenarios for the Ebro valley, Spain. Acta Horticulturae, 803, 131-138.

Marta AD, Grifoni D, Mancini M, Storchi P, Zipoli G, Orlandini S (2010) Analysis of the relationships between climate variability and grapevine phenology in the Nobile di Montepulciano wine production area. The Journal of Agricultural Science, 148, 657666.

May P (2000) From bud to berry, with special reference to inflorescence and bunch morphology in Vitis vinifera L. Australian Journal of Grape and Wine Research, 6, 82-98.

McIntyre GN, Lider LA, Ferrari NL (1982) The Chronological Classification of Grapevine Phenology. American Journal of Enology and Viticulture, 33, 80-85.

Mearns LO, Easterling W, Hays C, Marx D (2001) Comparison of agricultural impacts of climate change calculated from high and low resolution climate change scenarios: Part I. The uncertainty due to spatial scale. Climatic Change, 51, 131-172.

Meier N, Rutishauser T, Pfister C, Wanner H, Luterbacher J (2007) Grape harvest dates as a proxy for Swiss April to August temperature reconstructions back to AD 1480. Geophysical Research Letters, 34, L20705.

Mira de Orduña R (2010) Climate change associated effects on grape and wine quality and production. Food Research International, 43, 1844-1855.

Molitor D, Caffarra A, Sinigoj P, Pertot I, Hoffmann L, Junk J (2014a) Late frost damage risk for viticulture under future climate conditions: a case study for the Luxembourgish 
winegrowing region. Australian Journal of Grape and Wine Research, 20, 160-168.

Molitor D, Junk J, Evers D, Hoffman L, Beyer M (2014b) A High-Resolution Cumulative

Degree Day-Based Model to Simulate Phenological Development of Grapevine. American Journal of Enology and Viticulture 65, 72-80.

Moncur MW, Rattigan K, Mackenzie DH, McIntyre GN (1989) Base Temperatures for Budbreak and Leaf Appearance of Grapevines. American Journal of Enology and Viticulture, 40, 21-26.

Moran W (1993) The Wine Appellation as Territory in France and California. Annals of the Association of American Geographers, 83, 694-717.

Morin X, Chuine I (2014) Will tree species experience increased frost damage due to climate change because of changes in leaf phenology? Canadian Journal of Forest Research, $44,1555-1565$.

Moriondo M, Bindi M, Fagarazzi C, Ferrise R, Trombi G (2011) Framework for highresolution climate change impact assessment on grapevines at a regional scale. Regional Environmental Change, 11, 553-567.

Moriondo M, Jones GV, Bois B, Dibari C, Ferrise R, Trombi G, Bindi M (2013) Projected shifts of wine regions in response to climate change. Climatic Change, 119, 825-839.

Moriondo M, Ferrise R, Trombi G, Dibari C, Bindi M (2015) Modelling olive trees and grapevines in a changing climate. Environmental modelling \& Software, 72, 387-401.

Mosedale JR, Wilson RJ, Maclean IMD (2015) Climate Change and Crop Exposure to Adverse Weather: Changes to Frost Risk and Grapevine Flowering Conditions. PLoS ONE, 10, e0141218.

Mukaetov, Zoran, Boskov, Poposka (2013) Assessing viticulture vulnerability in the Vardar planning region for the design of adaptation measures to climate change. Ministry of Envvironment and Physical Planning, Skopje, Republic of Macedonia. Available at: 
http://www.undp.org/content/dam/the_former_yugoslav_republic_of_macedonia/docs /Assessing_Viticulture_Vulnerability_ENGLISH.pdf

Muresu MP (2012) Impacts of climate change on grapevine: the use of crop model WinStics to estimate potential impacts on grapevine (Vitis vinifera L.) in Sardinia scale. $\mathrm{PhD}$ thesis, Sassari, Italy.

Myles S, Boyko AR, Owens CL et al. (2011) Genetic structure and domestication history of the grape. Proceedings of the National Academy of Sciences, 108, 3530-3535.

Nemani RR, White MA, Cayan DR, Jones GV, Running SW, Coughlan JC, Peterson DL (2001) Asymmetric warming over coastal California and its impact on the premium wine industry. Climate Research, 19, 25-34.

Nendel C, Kersebaum KC (2004) A simple model approach to simulate nitrogen dynamics in vineyard soils. Ecological Modelling, 177, 1-15.

Nesbitt A, Kemp B, Steele C, Lovett A, Dorling S (2016) Impact of recent climate change and weather variability on the viability of UK viticulture - combining weather and climate records with producers' perspectives. Australian Journal of Grape and Wine Research, 22, 324-335.

Neumann PA, Matzarkis A (2014) A simple model for the estimation of wine characteristics in SW Germany. Theoretical and Applied Climatology, 116, 259-271.

Ollat N, Diakou-Verdin P, Carde J-P, Barrieu F, Gaudillère J-P, Moing A. (2002) Grape berry development : A review. Journal International des Sciences de la Vigne et du Vin, 36, 109-131.

Ollson C, Jönsson AM (2015) Budburst model performance: the effect of the spatial resolution of data sets. Agricultural and Forest Meteorology 200, 302-312.

Ostrom E (2015) Governing the Commons. Cambridge University Press, 297 pp.

Overton J (2010) The consumption of space: Land, capital and place in the New Zealand 
wine industry. Geoforum, 41, 752-762.

Overton J, Heitger J (2008) Maps, markets and Merlot: The making of an antipodean wine appellation. Journal of Rural Studies, 24, 440-449.

Pacifici M, Foden WB, Visconti P et al. (2015) Assessing species vulnerability to climate change. Nature Climate Change, 5, 215-224.

Pallas B, Loi C, Christophe A, Cournède PH, Lecoeur J (2010) Comparison of three approaches to model grapevine organogenesis in conditions of fluctuating temperature, solar radiation and soil water content. Annals of Botany, 107, 729-745.

Palusuo T, Kersebaum KC, Angulo C, et al. (2011) Simulation of winter wheat yield and its variability in different climates of Europe: a comparison of eight crop growth models. European Journal of Agronomy, 35, 103-114.

Park SE, Marshall NA, Jakku E, Dowd AM, Howden SM, Mendham E, Fleming A (2012) Informing adaptation responses to climate change through theories of transformation. Global Environmental Change, 22, 115-126.

Parker AK, Cortázar-Atauri, IG, van Leeuwen C, Chuine I (2011) General phenological model to characterise the timing of flowering and veraison of Vitis vinifera $\mathrm{L}$. Australian Journal of Grape and Wine Research, 17, 206-216.

Parker AK, Hofmann RW, van Leeuwen C, McLachlan ARG, Trought MCT (2014) Leaf area to fruit mass ratio determines the time of veraison in Sauvignon Blanc and Pinot Noir grapevines. Australian Journal of Grape and Wine Research, 20, 422-431.

Patchell J (2008) Collectivity and differentiation: a tale of two wine territories. Environment and Planning A, 40, 2364-2383.

Paterson T (2004) Australian Chardonnay: past, present and future. Journal of Wine Research, 15, 135-169.

Pereira GE, Gaudilliere J-P, Pieri P, Hilbert G, Maucourt M, Deborde C, Moing A, Rolin D 
(2006) Microclimate Influence on Mineral and Metabolic Profiles of Grape Berries. Journal of Agricultural and Food Chemistry, 54, 6765-6775.

Petrie PR, Clingeleffer PR (2005) Effects of temperature and light (before and after budburst) on inflorescence morphology and flower number of Chardonnay grapevines (Vitis vinifera L.). Australian Journal of Grape and Wine Research, 11, 59-65.

Petrie PR, Clingeleffer PR (2006) Crop thinning (hand versus mechanical), grape maturity and anthocyanin concentration: outcomes from irrigated Cabernet Sauvignon (Vitis vinifera L.) in a warm climate. Australian Journal of Grape and Wine Research, 12, 21-29.

Petrie PR, Sadras VO (2008) Advancement of grapevine maturity in Australia between 1993 and 2006: putative causes, magnitude of trends and viticultural consequences. Australian Journal of Grape and Wine Research, 14, 33-45.

Pieri P, Gaudillère JP (2015) Sensitivity to training system parameters and soil surface albedo of solar radiation intercepted by vine rows. VITIS - Journal of Grapevine Research, $42,77$.

Pohl C, Rist S, Zimmermann A et al. (2010) Researchers' roles in knowledge co-production: experience from sustainability research in Kenya, Switzerland, Bolivia and Nepal. Science and Public Policy, 37, 267-281.

Poni S, Bernizzoni F, Civardi S, Libelli N (2009) Effects of pre-bloom leaf removal on growth of berry tissues and must composition in two red Vitis vinifera L. cultivars. Australian Journal of Grape and Wine Research, 15, 185-193.

Poni S, Palliotti A, Bernizzoni F (2006) Calibration and Evaluation of a STELLA Softwarebased Daily CO2 Balance Model in Vitis vinifera L. Journal of the American Society for Horticultural Science, 131, 273-283.

Porter M (1998) Clusters and the New Economics of Competition. Harvard Business Review, 
76, 77-90. Connaissance Vigne et Vin, 15, 65-79.

Porter JR, Xie L, Challinor AJ, Howden M, Iqbal MM, Lobell DB, Travasso MI (2014)

Chapter 7: Food Security and Food Production. In: Climate change 2014: impacts, adaptation and vulnerability. Working Group II Contribution to the IPCC 5th Assessment Report, (eds Field CB, Barros VR, Dokken DJ, Mach KJ, Mastrandrea MD, Bilir TE, Chatterjee M, Ebi KL, Estrada YO, Genova RC, Girma B, Kissel ES, Levy AN, MacCracken S, Mastrandrea PR, White LL), pp. 485-533, Cambridge University Press.

Potter KA, Arthur Woods H, Pincebourde S (2013) Microclimatic challenges in global change biology. Global Change Biology, 19, 2932-2939.

Pouget R (1981) Action de la température sur la différenciation des inflorescences et des fleurs durant les phases de prédébourrement et de post-débourrement des bourgeons latents de la vigne. Connaissance Vigne et Vin, 15, 65-79.

Pratt C (1971) Reproductive Anatomy in Cultivated Grapes - A Review. American Journal of Enology and Viticulture, 22, 92-109.

Prieto JA, Louarn G, Perez Peña J, Ojeda H, Simonneau T, Lebon E (2012) A leaf gas exchange model that accounts for intra-canopy variability by considering leaf nitrogen content and local acclimation to radiation in grapevine (Vitis vinifera L.). Plant, Cell \& Environment, 35, 1313-1328.

Ramirez CD (2008) Wine Quality, Wine Prices, and the Weather: Is Napa “Different"? Journal of Wine Economics, 3, 114-131.

Ramos M, Jones G, Martínez-Casasnovas J (2008) Structure and trends in climate parameters affecting winegrape production in northeast Spain. Climate Research, 38, 1-15.

Rickards L, Howden SM (2012) Transformational adaptation: agriculture and climate change. Crop and Pasture Science, 63, 240-250. 
$\underline{\text { Rodo X, Comin FA (2000) Links between large-scale anomalies, rainfall and wine quality in }}$ the Iberian Peninsula during the last three decades. Global Change Biology, 6, 267273.

Rosenzweig C, Jones JW, Hatfield JL et al. (2013) The Agricultural Model Intercomparison and Improvement Project (AgMIP): Protocols and pilot studies. Agricultural and Forest Meteorology, 170, 166-182.

Rötter R, Geijn SC van de (1999) Climate Change Effects on Plant Growth, Crop Yield and Livestock. Climatic Change, 43, 651-681.

Rötter RP, Carter TR, Olesen JE, Porter JR (2011) Crop-climate models need an overhaul. Nature Climate Change, 1, 175-177.

Rötter RP, Palosuo T, Kersebaum KC, et al. (2012) Simulation of spring barley yield in different climatic zones of Northern and Central Europe: A comparison of nine crop models. Field Crops Research, 133, 23-36.

Sadras VO, Moran MA (2012) Elevated temperature decouples anthocyanins and sugars in berries of Shiraz and Cabernet Franc. Australian Journal of Grape and Wine Research, 18, 115-122.

Sadras VO, Moran MA (2013) Nonlinear effects of elevated temperature on grapevine phenology. Agricultural and Forest Meteorology, 173, 107-115.

$\underline{\text { Sadras VO, Petrie PR (2011) Climate shifts in south-eastern Australia: early maturity of }}$ Chardonnay, Shiraz and Cabernet Sauvignon is associated with early onset rather than faster ripening. Australian Journal of Grape and Wine Research, 17, 199-205.

Salazar-Parra C, Aguirreolea J, Sanchez-Diaz M, Irigoyen JJ, Morales F (2012)

Photosynthetic response of Tempranillo grapevine to climate change scenarios. Annals of Applied Biology, 161, 277-292.

Salinger MJ (1987) Impact of climatic warming on the New Zealand growing season. 
Journal of the Royal Society of New Zealand, 17, 363-371.

Sánchez LA, Dokoozlian NK (2005) Bud Microclimate and Fruitfulness in Vitis vinifera L. American Journal of Enology and Viticulture, 56, 319-329.

Santos JA, Malheiro AC, Karremann MK, Pinto JG (2011) Statistical modelling of grapevine yield in the Port Wine region under present and future climate conditions. International Journal of Biometeorology, 55, 119-131.

Santos JA, Grätsch SD, Karremann MK, Jones GV, Pinto JG (2012) Ensemble projections for wine production in the Douro Valley of Portugal. Climatic Change, 117, 211-225.

$\underline{\text { Semenov MA, Barrow EM (1997) Use of a stochastic weather generator in the development }}$ of climate change scenarios. Climatic Change, 35, 397-414.

Schamel G, Anderson K (2003) Wine Quality and Varietal, Regional and Winery

Reputations: Hedonic Prices for Australia and New Zealand. Economic Record, 79, 357-369.

Schultz HR, Stoll M (2009) Some critical issues in environmental physiology of grapevines: future challenges and current limitations. Australian Journal of Grape and Wine Research, 16, 4-24.

Shakak Y, Gal E, Offir Y, Ben-Yakir D (2008) Photoselective shade netting integrated with greenhouse technologies for improved performance of vegetable and ornamental crops. Acta Horticulturae, 797, 75-80.

Shaw AB (1999) The emerging cool climate wine regions of eastern Canada. Journal of Wine Research, 10, 79-94.

Slovic P (1987) Perception of risk. Science, 236, 280-285.

Smart RE (1985) Principles of Grapevine Canopy Microclimate Manipulation with Implications for Yield and Quality. A Review. American Journal of Enology and Viticulture, 36, 230-239. 
Smart RE, Dick JK, Gravett IM, Fisher BM, others (1990) Canopy management to improve grape yield and wine quality-principles and practices. S. Afr. J. Enol. Vitic, 11, 3-17.

Stöckle CO, Donatelli M, Nelson R (2003) CropSyst, a cropping systems simulation model. European Journal of Agronomy, 18, 289-307.

Suggitt AJ, Gillingham PK, Hill JK, Huntley B, Kunin WE, Roy DB, Thomas CD (2011) Habitat microclimates drive fine-scale variation in extreme temperatures. Oikos, 120 , $\underline{1-8 .}$

This P, Lacombe T, Thomas MR (2006) Historical origins and genetic diversity of wine grapes. Trends in Genetics, 22, 511-519.

Thomas CD, Cameron A, Green RE et al. (2004) Extinction risk from climate change. Nature, 427, 145-148.

Tognetti R, Raschi A, Longobucco A, Lanini M, Bindi M (2005) Hydraulic properties and water relations of Vitis vinifera L. exposed to elevated $\mathrm{CO} 2$ concentrations in a free air CO2 enrichment (FACE). Phyton, 45, 243-256.

Tomasi D, Jones GV, Giust M, Lovat L, Galotti F (2011) Grapevine Phenology and Climate Change: Relationships and Trends in the Veneto Region of Italy for 1964-2009. American Journal of Enology and Viticulture, 62, 329-339.

Tonietto J, Carbonneau A (2004) A multicriteria climatic classification system for grapegrowing regions worldwide. Agricultural and Forest Meteorology, 124, 81-97.

Urhausen S, Brienen S, Kapala A, Simmer C (2011) Must quality estimation based on climate data in the Upper Moselle region. Meteorologische Zeitschrift, 20, 479-486.

Vaudour E (2002) The Quality of Grapes and Wine in Relation to Geography: Notions of Terroir at Various Scales. Journal of Wine Research, 13, 117-141.

Verdú Jover AJ, Lloréns Montes FJ, Fuentes Fuentes M (2004) Measuring perceptions of quality in food products: the case of red wine. Food Quality and Preference, 15, 453- 
469.

Watt AM, Dunn GM, May PB, Crawford SA, Barlow EWR (2008) Development of inflorescence primordia in Vitis vinifera L. cv. Chardonnay from hot and cool climates. Australian Journal of Grape and Wine Research, 14, 46-53.

Webb L, Whetton P, Barlow E (2007) Modelled impact of future climate change on the phenology of winegrapes in Australia. Australian Journal of Grape and Wine Research, 13, 165-175.

Webb L, Whetton P, Barlow E (2008) Climate change and winegrape quality in Australia. Climate Research, 36, 99-111.

Webb LB, Whetton PH, Bhend J, Darbyshire R, Briggs PR, Barlow EWR (2012) Earlier wine-grape ripening driven by climatic warming and drying and management practices. Nature Climate Change, 2, 259-264.

White AC, Rogers A, Rees M, Osborne CP (2016) How can we make plants grow faster? A source-sink perspective on growth rate. Journal of Experimental Botany, 67, 31-45.

White MA, Diffenbaugh NS, Jones GV, Pal JS, Giorgi F (2006) Extreme heat reduces and shifts United States premium wine production in the 21st century. Proceedings of the National Academy of Sciences, 103, 11217-11222.

White MA, Whalen P, Jones GV (2009) Land and wine. Nature Geoscience, 2, 82-84.

Wiens JA, Stralberg D, Jongsomjit D, Howell CA, Snyder MA (2009) Niches, models, and climate change: Assessing the assumptions and uncertainties. Proceedings of the National Academy of Sciences, 106, 19729-19736.

Wilby RL, Dawson, CW (2013) The Statistical Downscaling Model: insights from one decade of application. International Journal of Climatology, 33, 1707-1719.

Williams DW, Andris HL, Beede RH, Luvisi DA, Norton MVK, Williams LE (1985) Validation of a Model for the Growth and Development of the Thompson Seedless 
Grapevine. II. Phenology. American Journal of Enology and Viticulture, 36, 283-289.

Willis KJ, Bhagwat SA (2009) Biodiversity and Climate Change. Science, 326, 806-807.

Willsher K (2013) French winemakers count cost of devastating hailstorms. The Guardian, Friday 9 August 2013. http://www.theguardian.com/world/2013/aug/09/bordeauxwine-vineyards-hailstorms-damage

Wilson R, Davies ZG, Thomas CD, Stewart AJA, New TR, Lewis OT (2007) Insects and climate change: processes, patterns and implications for conservation. In: Insect Conservation Biology (eds Stewart AJA, New TR, Lewis OT), pp. 245-279, The Royal Entomological Society.

Wolkovich EM, Cook BI, Allen JM et al. (2012) Warming experiments underpredict plant phenological responses to climate change. Nature, 485, 494-497.

Xu Y, Castel T, Richard Y, Cuccia C, Bois B (2012) Burgundy regional climate change and its potential impact on grapevines. Climate Dynamics, 39, 1613-1626. 